\title{
Effect of quaternary ammonium compounds on microbial contamination levels in dental clinics
}

\author{
Sae Yun Baik', YounJung Park², Seung Ho Choi, Hee Jae Kim³, Seong Taek Kim* \\ 'Department of Laboratory Medicine, Seoul Clinical Laboratories, Yongin, Republic of Korea \\ 2Department of Orofacial Pain and Oral Medicine, Yonsei University College of Dentistry, Seoul, Republic of Korea \\ ${ }^{3}$ Lami Dental Clinic, Seoul, Republic of Korea
}

\begin{abstract}
The aim of this study was to investigate the change of microbial contamination levels in the different areas and at the different time points after application of a quaternary ammonium compound (QAC) that has mechanical antimicrobial effect. The microbial contamination levels were measured in three different areas; unit chair handle, spit sink area and hand piece holder at different time points using adenosine triphosphate (ATP) monitoring system and ATP surface test kit. Hand piece holder showed the highest level of microbial contamination. In most of the clinics, QAC significantly reduced the levels of microbial contamination, and maintained antimicrobial activity for 4 to 6 months. QAC may be used effectively in dental clinics due to the duration of antimicrobial effect and the minimal exposure of chemicals and further studies are needed with large sample size. (J Dent Rehabil Appl Sci 2020;36(1):55-60)
\end{abstract}

Key words: quaternary ammonium compounds (QAC); microbial contamination; ATP (adenosine triphosphate) monitoring system; dental clinic

서론

감염관리는 최근 신종 감염병의 출현과 환자안전에 대 한 사회적 관심이 증가됨에 따라 중요성이 강조되고 있 으며, 이것의 궁극적 목표는 의료 관련 감염발생을 최소 화 하는 것이다. 또한 병원 내 감염은 심각한 유병률, 사 망률 및 많은 의료비용을 야기하며 병원균의 교차 감염 과 확산은 지역사회와 타 대중 기관으로까지 전파될 수 있어 각별한 주의가 요구된다. 대한의료관련감염관리학 회 지침서인 의료기관의 감염관리 5 판에 따르면, 치과는 혈액과 구강 또는 호흡기분비물을 통해 다양한 미생물의 노출 가능성이 높아 환자와 치과 종사자 간의 교차감염 성이 높으므로, 치과 종사자는 환자 진료의 전 과정 동안 일련의 감염 예방활동을 통해 직무 중 감염노출과 환자

Correspondence to: Seong Taek Kim

Professor, Department of Orofacial Pain and Oral Medicine, Yonsei University College of Dentistry, Yonsei-ro 50-1, Seodaemun-gu, Seoul, 03722, Republic of

Korea

Tel: +82-2-2228-3110, Fax: +82-2-393-8076, E-mail: k8756050@yuhs.ac

Received: March 8, 2020/Last Revision: March 11, 2020/Accepted: March 12, 2020
간 감염전파를 최대한 예방하는 것이 중요하다고 기술하 였다. ${ }^{1}$

치과 진료실의 경우 더욱 중요하다. 매회 멸균 소독 된 진료기구를 사용하더라도 다제내성균(multidrugresistant organisms, MDROs)과 같은 유해 세균이나 독 감, 전염성 바이러스에 감염된 환자의 비말, 에어로졸 및 혈액접촉이 발생하여, 의료인 및 진료공간 내 다른 환자 들과 교차 감염의 위험성이 상당히 높다. 치료 전 문진으 로 이러한 병증을 가진 환자를 어느 정도 미리 알고 대처 할 수도 있지만, 환자 자신도 모르는 감염병에 노출된 경 우에는 이마저도 어렵다. 2019년 말에 중국 우한에서 발 병하여 전 세계를 공포에 몰아넣은 신종 코로나 바이러 스(COVID 19)의 경우 강한 전염력을 가진 무증상 감염 자의 존재가 보고되었으며, 이는 문진으로도 가려내기

Copyright@ 2020 The Korean Academy of Stomatognathic Function and Occlusion (c) It is identical to Creative Commons Non-Commercial License. 
힘들어 의료인 및 다른 환자들에게 극도로 위험한 요소 가 되었다. ${ }^{2}$

감염병 관리를 위하여 그동안 다양한 항균제가 개발 되고 사용되었는데, 이 중 4차 암모늄 화합물 (quaternary ammonium compounds, $\mathrm{QAC}$ )은 양전하를 띤 양친매성 고분자로써 음전하를 가진 세균 표면에 결합하여 세포막 을 파괴함으로써 항균효과를 나타낸다. ${ }^{3}$ 그러나 대부분 의 화합물들은 생체적합성(biocompatible) 및 생분해성 (biodegradable)이 떨어지는 단점이 있어, ${ }^{4}$ 최근 이를 보 완하여 미국 환경처와 대한민국 환경부에 허가 받은 $\mathrm{SD}$ (Spike Defender ${ }^{\mathrm{TM}}$ ) solution이 개발되어 병의원 및 다중 이용 시설에 사용되고 있다.

본 증례는 병원 내 감염관리를 위하여 이 SD solution 을 국내외 치과병의원의 주요 오염구역에 도포한 후에 ATP (adenosine triphosphate) 모니터링 시스템을 이용 하여 미생물 오염도 변화를 측정하고자 하였다.

\section{증례보고}

2018년 4월부터 2019년 11월까지 4차 암모늄 화합 물 항균제 SD (Spike Defender ${ }^{\mathrm{TM}}$, SDLabKorea, Seoul, Korea) solution을 도포한 태국 방콕 C대학 치과병원(유 니트 120 개 규모), 대한민국 서울 $\mathrm{M}$ 치과병원(유니트 30
개 규모), J 및 L치과의원(유니트 각각 36개, 6 개 규모) 등 총 4 곳의 국내외 치과병의원 진료실에서 감염되기 쉬운 유닛체어 핸들(unit chair handle), 타구대 표면(spit sink area), 핸드피스 거치대(hand piece holder)에 멸균된 면 봉을 이용하여 검체를 채취하고 항균제 도포 전과 후 수 차례 오염도를 측정하였다.

오염도 조사를 위하여 ATP 모니터링 시스템(SystemSURE Plus ${ }^{\mathrm{TM}}$, Hygiena, Watford, UK)과 ATP 표면검사 테스트(UltraSnap ${ }^{\mathrm{TM}}$, Hygiena) 키트를 사용하였다. ATP 모니터링 시스템은 모든 살아있는 세포에서 대사작용에 이용되는 에너지의 근원인 ATP의 양이 많아졌을 때 발 광하는 빛의 양을 측정함으로써 오염도를 측정하는 원리 이다. 이는 사용이 간편하고 기구의 표면오염 검사 및 종 사자의 오염 검사가 가능하여 소독기준의 적합여부를 실 시간으로 판단할 수 있다. ${ }^{5}$ RLU (Relative Light Unit)으 로 불리는 측정 단위는 빛의 상대적 발광수치를 의미하 고 ATP를 이용하는 검사결과에 많이 쓰이는데, 일반적 으로 적용되는 오염도 기준은 0 - $100 \mathrm{RLU}$ 정상, 101 $200 \mathrm{RLU}$ 한계수치, $200 \mathrm{RLU}$ 이상은 위생관리가 필요한 상태를 의미한다. ATP 모니터링 시스템의 사용 방법은 먼저 검체 채취(swab) 후 키트를 꺾어 눌러서 ATP 형광 반응을 유도하고 측정기에 키트를 넣으면 15 초 후 결과 측정치를 보여준다(Fig. 1). ${ }^{6}$
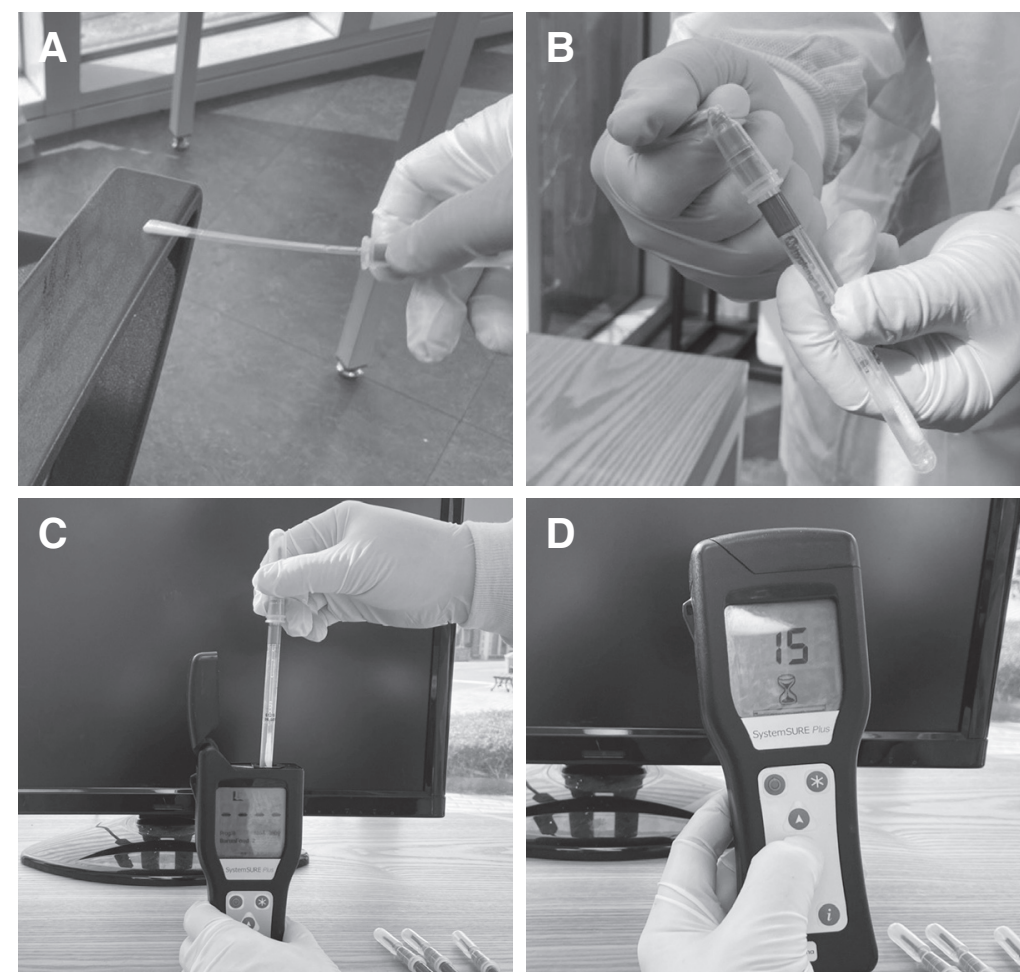

Fig. 1. The procedure of measuring ATP monitoring system. Surface swabbing $(A)$, snap the kit that illuminates ATP within a sample (B), and insert the kit into ATP monitoring system (C). It detects the luminescence and quantifies the amount of ATP in the sample in 15 seconds (D). 


\section{4차 암모늄 화합물 SD solution 도포 전 구역별 미 생물 오염도}

$\mathrm{SD}$ solution 도포 전 치과 진료실 내 구역별 미생물 오 염도는 유닛체어 손잡이의 평균 오염도가 702.5 RLU, 타 구대의 평균 오염도는 $1082 \mathrm{RLU}$, 핸드피스 거치대의 평 균 오염도는 $1455.8 \mathrm{RLU}$ 로 치과의사가 주로 사용하는 핸드피스 거치대가 가장 오염도가 높았다. 특징적으로 태국의 $\mathrm{C}$ 치과대학병원의 오염도가 국내 3 개의 치과병의 원 보다 현저히 낮았다(Table 1).

\section{4차 암모늄 화합물 SD solution 도포 후 시기별 미 생물 오염도의 변화}

진료실 내 대표적인 미생물 오염구역 세 군데인 유닛 체어 손잡이(Fig. 2A), 타구대(Fig. 2B), 핸드피스 거치대 (Fig. 2C)에 SD solution 도포 전과 후 시기별 오염도의 변화를 분석하였다. 도포 전 오염도가 높았던 진료실이 오염도가 낮았던 진료실 보다 도포 후 오염도의 감소율 이 뚜렷했으며, 특히 도포 후 1개월 오염도 보다 도포 후 4 개월 및 6개월의 오염도가 더 낮은 양상을 보였다.

\section{고찰}

최근 전 세계적인 유행병으로 번지는 신종 코로나 바 이러스의 경우, 기존의 바이러스와 달리 무생물 표면에 서 8 - 9일까지 생존한다는 보고가 있는 만큼 병원 공간 내 감염이 큰 위험요소가 되고 있다. ${ }^{7}$ 치과 진료실은 직 접적인 진료기구와 장비를 소독하는 것 이외에도 책상이 나 의자, 유닛체어, 시술 베드 등을 매 환자, 매 진료마다 지속적으로 소독해야 감염관리가 가능하지만, ${ }^{8}$ 대부분 의 병의원은 인력과 비용적인 부담으로 철저한 감염 관리

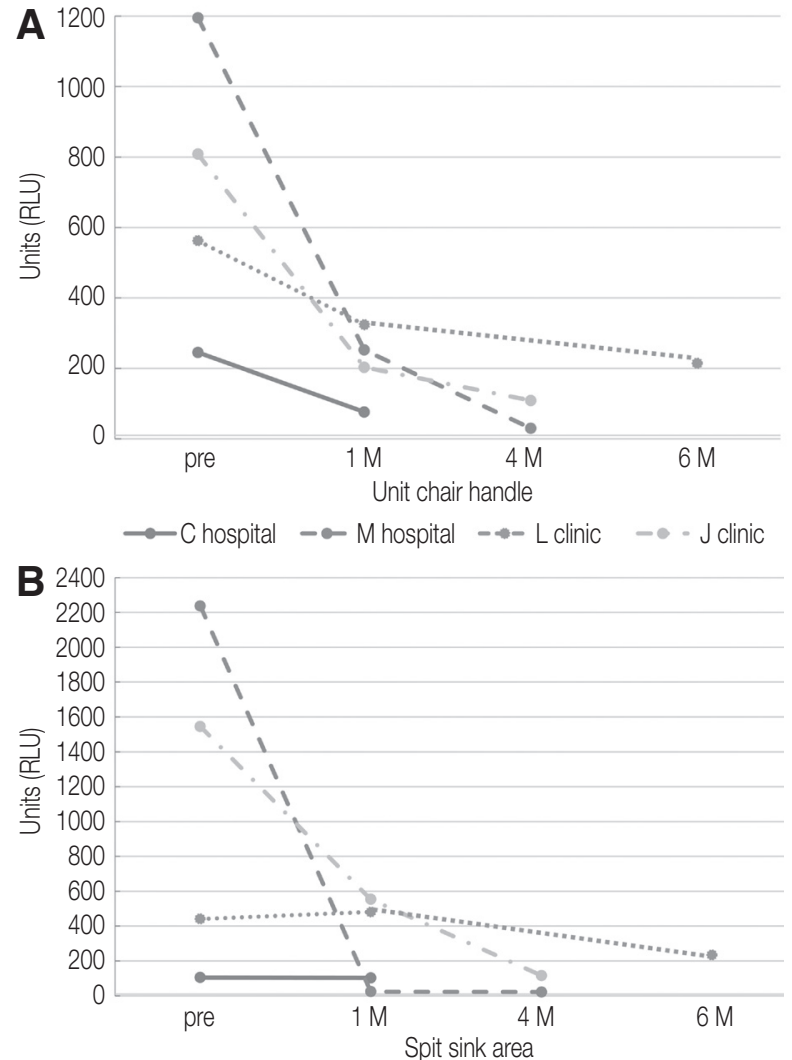

$\rightarrow$ C hospital $-\bullet$ M hospital $-\infty$ L clinic $-\bullet-J$ clinic

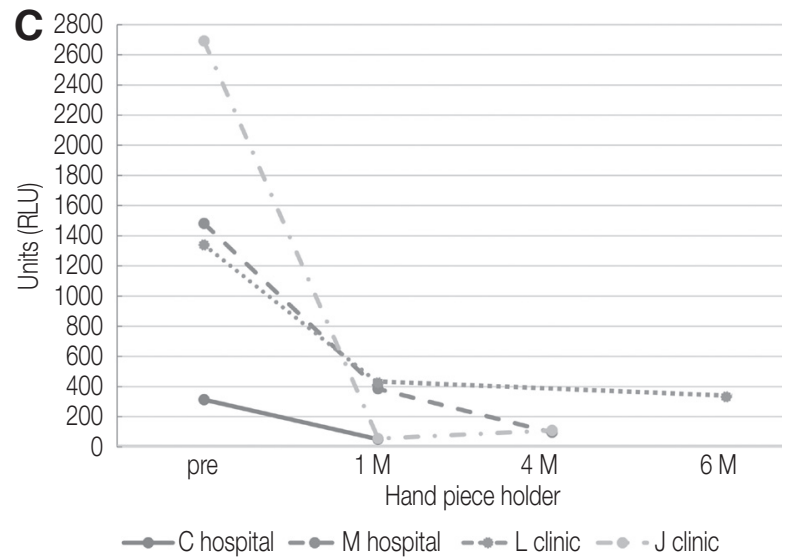

Fig. 2. The change of contamination levels in different areas at different time points (Units: RLU). (A) Unit chair handle, (B) Spit sink area, (C) Hand piece holder.

RLU: Relative light unit, Pre: Pre treatment, M: Month(s) of post treatment.

Table 1. The change of microbial contamination levels in different areas after application of quaternary ammonium compound (Units: RLU)

\begin{tabular}{lrrrrrrrrrrrr}
\hline & \multicolumn{3}{c}{ C hospital } & \multicolumn{3}{c}{ M hospital } & \multicolumn{3}{c}{ L clinic } & \multicolumn{3}{c}{ J clinic } \\
& pre & $1 \mathrm{M}$ & pre & $1 \mathrm{M}$ & $4 \mathrm{M}$ & pre & $1 \mathrm{M}$ & $6 \mathrm{M}$ & pre & $1 \mathrm{M}$ & $4 \mathrm{M}$ \\
\hline Unit chair handle & 245 & 76 & 1195 & 252 & 30 & 562 & 324 & 214 & 808 & 203 & 109 \\
Spit sink area & 105 & 103 & 2237 & 24 & 22 & 441 & 481 & 234 & 1545 & 554 & 116 \\
Hand piece holder & 313 & 50 & 1481 & 385 & 96 & 1339 & 424 & 331 & 2690 & 55 & 34 \\
\hline
\end{tabular}

RLU: Relative light unit, Pre: Pre treatment, M: Month(s) of post treatment. 


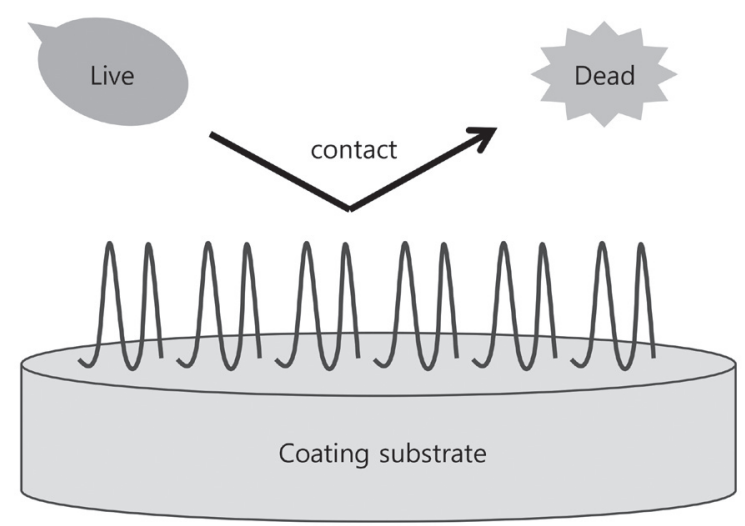

Fig. 3. Antimicrobial mechanism of quaternary ammonium compound ( $Q A C)$. The spike structures destroy the cell membrane of microorganisms mechanically and induce the cell death.

를 하기 힘든 것이 현실이다. 또한 화학적 살균소독제는 도포 후에 즉각적으로 화학성분이 휘발되기 때문에 의료 인이나 환자의 건강에도 영향을 줄 수 있기에 주위로 용 출되지 않는 새로운 방식의 항균제가 개발되어 왔다. 이 중 4차 암모늄 화합물은 물질 표면에 결합되어 미생물을 사멸시키는 원리를 이용한 접촉활성 항균물질(contact active antimicrobial materials)로써 강력한 항균력을 가 지며 내성 균주에도 효과적으로 작용한다고 보고되고 있 다. 그 작용기전은 표면 접촉 항균제가 물체의 표면에 공 유결합한 후 일정 기간 부착을 유지하면서 양전하를 가 지는 4급 질소와 음전하를 가지는 미생물막 사이에서 강 하게 끌어당김으로써 미생물막의 인지질을 손상시키면 서 표면 위로 접촉되는 미생물을 사멸시키는 원리로, 이 는 대량의 항균제 사용 시 발생하는 환경오염과 내성균 의 발생을 방지할 수 있다는 장점이 있다(Fig. 3). ${ }^{3}$

이에 본 증례는 최근에 환경부 허가를 받은 4 차 암모 늄 화합물 SD solution을 국내외 총 4곳의 치과병의원 주 요 오염 구역에 도포한 후에 ATP 모니터링 시스템을 이 용하여 미생물 오염도를 도포 전, 도포 후 1개월, 도포 후 4 개월 또는 6개월 반복하여 비교 측정하였다.

도포 전 미생물 오염도 측정 시, 윤 등의 이전연구에서 는 타구대의 오염도가 가장 높았는데, ${ }^{9}$ 본 증례에서는 치 과의사가 주로 사용하는 핸드피스 거치대가 가장 오염도 가 높았다. 이러한 결과의 차이점은 각 치과병의원의 진 료인 마다 소독 빈도, 정밀도 등 위생 관리 실태가 다양
한 결과로 사료된다. 또한 유닛체어 수로 평가한 의료기 관의 규모에 따른 도포 전 미생물 오염도는 태국의 C치 과대학병원이 국내 3 개의 치과병의원 보다 현저히 낮았 는데 이는 규모와 상관없이 병의원의 소독규정이나 이에 대한 관리가 더 중요한 요소로 추측되며, 오염도 측정 대 상 병의원이 비록 소수였지만 국외 진료실에 비해 국내 진료실에 각별한 감염관리가 필요할 것으로 사료된다. 또한 특징적인 것은 도포 후 1개월 오염도 보다 도포 후 4개월 및 6 개월 후 오염도가 더 낮은 양상을 보였는데 이 는 1회의 4차 암모늄 화합물 도포만으로도 대략 4- 6개 월 정도 비교적 장기간 항균효과가 지속됨을 추측할 수 있었다.

본 증례에서 오염도 조사를 위하여 사용한 ATP 모니 터링 시스템와 ATP 표면검사 테스트 키트는 표면 미생 물 군집 수를 신속하게 측정하여 실시간으로 조치를 취 할 수 장점이 있으나, 측정 시 박테리아, 바이러스 뿐만 아니라 타 미생물 및 음식 잔류 등의 유기물도 측정값에 포함될 수 있어 표면 미생물의 존재가 과대평가될 수 있 다. 그렇지만 Jagrosse 등은 이 테스트 방법이 병원의 위 생상태를 모니터링 하기에 효과적인 도구로 보고 하였 다. ${ }^{10}$ ATP 모니터 미생물 오염도에서 위생관리가 요구되 는 한계치를 본 증례에서는 $200 \mathrm{RLU}$ 로 엄격하게 적용하 였으나 이전 연구에서 $250 \mathrm{RLU}$ 로도 보고된 바 있다. ${ }^{1}$

Yun 등의 연구는 본 증례에서 사용한 미생물 전반의 오염도 측정과는 달리 오로지 표면에 존재하는 세균 수 와 순수 분리된 세균을 동정하여 원내감염을 일으킬 수 있는 특정 세균을 확인하였는데 유닛체어, 라이트 손잡 이, 타구대 표면에서 검출된 세균의 종류를 확인한 결과 그람양성 균주는 $47.3 \%$, 그람음성 균주는 $52.7 \%$ 로 그 람음성 균주가 조금 높게 분포하고 있음을 밝혀냈다. 따라서 향후 후속 연구에서는 사용이 간단하고 편리한 ATP 모니터링 시스템 뿐만 아니라 치과 진료실 여러 표 면에 존재하는 세균 수와 다양한 세균을 동정하는 연구 가 필요할 것으로 사료된다. 특히 치아 우식증과 임프란 트의 감염에 관련된 그람양성 균주 Streptococcus mutans와 Staphylococcus aureus 를 진료실에서 오염 구역별 측정하거 나, ${ }^{12}$ 환자가 매일 사용하는 칫솔, 치실 등 구강 위생 관 련 도구나 치과 진료 장비의 상태에 따라 세균의 수를 측 정하는 세균 배양 실험 ${ }^{13}$ 등을 통해 4 차 암모늄 화합물의 항균효과를 좀 더 객관적으로 평가를 함으로써 감염경로 차단과 감염관리 개선을 도모할 수 있을 것으로 사료된 다. 


\section{결론}

물리적으로 항균효과를 나타내는 4차 암모늄 화합물 을 사용하여 치과 진료실의 주요 오염 구역에 도포한 후 시기별 오염도 변화를 측정한 결과, 도포 전 상대적으로 오염도가 높은 진료실이 오염도가 낮은 진료실 보다 도 포 후 현저한 오염도의 감소를 보였다. 또한 도포 후 시 기별 오염도의 변화를 분석한 결과 대부분의 진료실에서 현저한 오염도의 감소를 보였으며, 대략 4 - 6 개월 정도 효과가 지속되는 양상을 보였다. 따라서 항균효과의 지 속성과 최소량의 화학성분 노출이라는 장점으로 향후 대 단위 후속연구를 통해 4차 암모늄 화합물이 치과 진료실 에서 효과적으로 사용될 수 있을 것으로 기대된다.

\section{ORCID}

Sae Yun Baik https://orcid.org/0000-0001-6115-8766

YounJung Park https://orcid.org/0000-0002-9152-7849

Seong Taek Kim https://orcid.org/0000-0001-9506-5103

\section{References}

1. Infection Control and Prevention in Healthcare Facilities. Korean Society for Healthcare-associated infection Control and Prevention. 5th ed. Seoul; Hanmibook; 2017. p. 497-513.

2. Hoehl S, Berger A, Kortenbusch M, Cinatl J, Bojkova D, Rabenau H, Behrens P, Böddinghaus B, Götsch U, Naujoks F, Neumann P, Schork J, TiarksJungk P, Walczok A, Eickmann M, Vehreschild M, Kann G, Wolf T, Gottschalk R, Ciesek S. Evidence of SARS-CoV-2 Infection in Returning Travelers from Wuhan, China. N Engl J Med 2020 Feb 18. doi: 10.1056/NEJMc2001899.

3. Elena P, Miri K. Formation of contact active antimicrobial surfaces by covalent grafting of quaternary ammonium compounds. Colloids Surf B Biointerfaces 2018;169:195-205.

4. Cho JH. Updates on Antimicrobial coating agent. ISBC newsletter 2017;5:1.

5. Lee JS, Jeong KH, Kim GH, Im IC, Kewon DC, Goo EH, Dong KR, Chung WK. Radiology Department Infection Control According to Radiography Frequency and Disinfection Period. J Korean
Soc Radiol 2011;5:73-80.

6. Hygiena. SystemSURE Plus ATP Monitoring System Instruction Manual. 2016.

7. Kampf G, Todt D, Pfaender S, Steinmann E. Persistence of coronaviruses on inanimate surfaces and their inactivation with biocidal agents. J Hosp Infect 2020;104:246-51.

8. Saeb A, Mody L, Gibson K. How are nursing homes cleaned? Results of a survey of 6 nursing homes in Southeast Michigan. Am J Infect Control 2017;45:e119-22.

9. Yun KO, Kim HY. A Study Regarding Bacterial Contamination of Surfaces in Dental Offices. Korean J Clin Lab Sci 2015;47:279-85.

10. Jagrosse D, Bommarito M, Stahl JB. Monitoring the Cleaning of Surgical Instruments with an ATP Detection System. Am J Infection Control 2012;40: e90-1.

11. Lewis T, Griffith C, Gallo M, Weinbren M. A modified ATP benchmark for evaluating the cleaning of some hospital environmental surfaces. J Hosp Infect 2008;69:156-63.

12. Wang H, Ren D. Controlling Streptococcus mutans and Staphylococcus aureus biofilms with direct current and chlorhexidine. AMB Express 2017;7:204.

13. Lee SG, Kang BR, Kim HS, Park HH, Park HR, Yoon SK, Nam SH. Changes in the number of bacteria in a toothbrush according to the toothbrush management method. Biomed Res 2017;28:73067310. 


\title{
치과 진료실의 미생물 오염도에 대한 4차 암모늠 화합물의 효과
}

\author{
백세연 ${ }^{1}$ 전문의, 박연정 ${ }^{2}$ 임상연구조교수, 최승호 ${ }^{3}$ 개원의, 김희재 ${ }^{3}$ 개원의, 김성택 ${ }^{2 *}$ 교수
}

${ }^{1}$ 서울의과학연구소 진단검사의학과

${ }^{2}$ 연세대학교 치과대학 구강내과학교실

${ }^{3}$ 라미치과의원

물리적 항균효과를 나타내는 4차 암모늄 화합물을 치과 진료실 미생물 주요 오염 구역에 도포 후 시기별 오염도의 변화 를 측정하고자 하였다. 4 개의 국내외 치과병의원에서 미생물 감염이 쉬운 유닛체어 핸들, 타구대 표면, 핸드피스 거치대 등에 ATP (adenosine triphosphate) 모니터링 시스템과 ATP 표면검사 테스트 키트를 사용하여 항균제 도포 전과 후 시 기별 오염도를 비교 측정하였다. 4차 암모늄 화합물 도포 전 구역별 미생물 오염도는 치과의사가 주로 사용하는 핸드피 스 거치대가 가장 높았다. 도포 후 시기별 오염도의 변화를 분석한 결과 대부분의 진료실에서 현저한 오염도의 감소를 보 였으며, 대략 4-6개월 정도 효과가 지속되는 양상을 보였다. 항균효과의 지속성과 최소량의 화학성분 노출이라는 장점으 로 향후 대단위 후속연구를 통해 4차 암모늄 화합물이 치과 진료실에서 효과적으로 사용될 수 있을 것으로 기대된다.

(구강회복응용과학지 2020;36(1):55-60)

주요어: 4차 암모늄 화합물; 미생물 오염; ATP (adenosine triphosphate) 모니터링 시스템; 치과 진료실

*교신저자: 김성택

(03722) 서울특별시 서대문구 연세로 50-1 연세대학교 치과대학병원 구강내과

Tel: 02-2228-3110 | Fax: 02-393-8076 | E-mail: k8756050@yuhs. ac

접수일: 2020년 3월 8일 | 수정일: 2020년 3월 11일 | 채택일: 2020년 3월 12일

60 